\title{
Emotional Intelligence of School Children
}

\author{
Daneshwari Onkari*, Sushma, Gowthami and Nishmitha \\ Department of Home Science, Shri Dharmastala Manjunatheshwara College, \\ Ujire, Dakshina Kannada, Karanataka, India \\ *Corresponding author
}

\begin{abstract}
A B S T R A C T
Keywords

Emotional intelligence,

Self awareness,

Emotional stability,

Empathy

\section{Article Info}

Accepted:

28 August 2020

Available Online:

10 September 2020

The study was conducted in rural and urban area of Beltangadi Taluka of Karnataka state during the year 2019-20. The research design followed was correlation and differential design. 120 samples were randomly selected. The results revealed that, 76.7 per cent, 45.0 per cent and 60.8 per cent of the rural, urban and total children belonged to high range of emotional intelligence respectively. There was significant association, relation and difference between emotional intelligence and locality. As per the mean values, children from urban area found to have higher emotional intelligence than rural children. There was significant difference between rural an urban areas children with respect to self awareness, managing relations and integrity and as per mean values, children from urban areas were better than children from rural areas. Family type and locality were found to be significantly predicting the emotional intelligence of children in Belthangadi taluk. They together explained 9.0 per cent of variance in emotional intelligence of children.
\end{abstract}

\section{Introduction}

Emotional Intelligence (EI) is a construct that has aroused interest in psychological research in recent decades (Bar-On, 2010). The first authors who proposed a formal definition model of EI were Salovey and Mayer (1993 and 1995), defining it as "the subset of social intelligence that involves the ability to monitor one's own and others' feelings and emotions, to discriminate among them, and to use this information to guide one's thinking and actions".
"Emotional Intelligence [1995], Goleman pointed out that as people, we have two minds, one that thinks and one that feels, and they interact to construct our mental life. The rational mind is the mode of comprehension with which we are aware, more awake, more thoughtful, and better able to consider and reflect. The emotional mind is another kind of more impulsive and powerful knowledge that can sometimes be illogical. Emotional skills are considered predictive of better facing daily life events, and higher levels of wellbeing and psychological adjustment. There is some evidence that Emotional Intelligence, 
defined as the skill to perceive, assimilate, understand and regulate our own emotions and those of others plays a key role as a person's own resource.

Most of the psychologists specialized in the study of emotional intelligence and the psychology of emotions, believe that the basic emotions are the following: happiness, surprise sadness, fear, anger, to these are added shame, guilt, despise, curiosity. All these basic emotions are involved in the settlement of the fundamental issues of current life, which demands prompt reaction.

The expression of the basic emotions is universal therefore they can be quickly and correctly recognized. These multiple emotional expressions (facial expression, gesture, posture, tone of voice) are consistent. Understanding them is not equally easy at every age of the children hence the present study is undertaken with following objectives includes, to study the emotional intelligence of school children; to know the difference between the emotional intelligence of rural and urban school children and also to assess the impact of selected variables on emotional intelligence.

\section{Materials and Methods}

The study was conducted in rural and urban area of Beltangadi Taluka of Karnataka state during the year 2019-20. The research design followed was correlation and differential design. Beltangadi city was considered as urban population and Ujire was taken as rural area. In Beltangadi, there are 11 schools and 7 schools found in Ujire. From these schools, 120 samples were randomly selected.

Emotional intelligence scale by Anukool et al., (2001), Socio-Economic Status Scale Developed by Agrawal et al., (2005) and Structured Personal Schedule were used for data collection. Emotional Intelligence Scale (EIS) developed by Anukool Hyde, Sanjoy Lethe and Upinder Dhar in the year 2001 measures 10 areas of emotional intelligence. They are self-awareness, empathy, self motivation, emotional stability, managing relations, integrity, self-development, value orientation, commitment and altruistic behavior. The reliability of the scale found to be 0.85 by Cronbach's alpha and 0.779 by Guttman split-half coefficient. The SocioEconomic Status scale consists of 22 statements which assess caste, education, occupation and monthly per capita income from all sources, type of house and location, family possessions and possessions of earning members in the family, number of children and possessions of agriculture and nonagricultural land along with animals and social status of the family. The scores were given for different dimensions and added to obtain total score. The Socio Economic Status has been classified as upper high, high, upper middle, lower middle, poor middle and very poor. The structured questionnaire was used to collect personal information like name, gender, age, birth order, education, and name of the family member with their age, relationship with the subject, family size, family type and annual income.

\section{Operational definition of Emotional intelligence}

The ability to monitor one's own and other people's emotions, to discriminate between different emotions and label them appropriately, and to use emotional information to guide thinking and behavior. The questionnaire was developed by Anukool et al., 2001 this consists of 34 statements with 10 areas, viz. self-awareness, empathy, self motivation, emotional stability, managing relations, integrity, self-development, value orientation, commitment and altruistic behavior.. The score of ranges from 34 to 170. 


\section{Results and Discussion}

The demographic information of rural and urban children is presented in Table 1 . The total numbers of samples were 120. Among these $60(50 \%)$ were from rural area and 60 were from urban area. In rural area, 51.7 per cent were boys and 48.3 per cent were girls. In urban area, 53.3 per cent were boys and 46.7 per cent were girls. Totally, 52.5 per cent were boys and 47.5 per cent girls. 37.5 per cent of them were in the age range of 7-8 years, 41.7 per cent were found in 9-10 years and 30.8 per cent in 11-12 years of age. As per birth order, 41.7 per cent, 55.0 per cent, and 48.3 per cent were first born in rural area, urban area and total sample respectively. About 5.0 per cent, 16.7 per cent and 10.8 per cent of the sample of children were single children's in rural area, urban area and total sample respectively, 50.0 per cent in rural area, 43.3 per cent in urban area and 46.7 per cent at total had one sibling. But 45.0 per cent, 40.0 per cent and 42.5 per cent had 2 or more number of siblings in Beltangady taluk. It was observed that majority of the households were nuclear in both rural and urban area is 81.7 per cent and 75.0per cent (totally $82.5 \%$ ). Majority of the children were from small size family. About 75.0 per cent of the children were from lower middle socioeconomic status and only 25.0 per cent were from upper middle socio-economic status. In rural and urban 78.3 per cent and 71.7 per cent were from lower socio-economic status, 21.7 per cent and 28.3 per cent were from upper socio-economic status respectively.

Percentage distribution of areas of emotional intelligence of children by locality is presented in table 2. Emotional intelligence scale consists of 10 areas of emotional intelligence and through these we can assess overall emotional intelligence. In case of selfawareness, majority $(81.7 \%$ and $93.3 \%)$ of the sample from rural and urban area were having high range of self-awareness followed by normal range. With respect to empathy, 75.0 per cent of the children were having high range of empathy followed by normal range in rural area. The similar result was found in urban area is 71.7 per cent were having high range of empathy followed by 28.3 per cent in normal range. Regarding self motivation, 83.3 per cent of children were having high range of self motivation. In case of emotional stability, 18.3 per cent and 81.7 per cent of rural children belonged to normal and high range of emotional stability respectively and 15.0 per cent and 85.0 per cent of urban children were under normal and high range of emotional stability respectively. 16.7 per cent and 83.3 per cent of total children were found in normal and high range of emotional stability. With respect to managing relations, 48.3 per cent, 21.7 per cent and 35.0 per cent of the rural, urban and total children belonged to normal range of managing relations respectively. With regard to integrity, 88.3 per cent, 91.7 per cent and 90.0 per cent of the rural, urban and total children belonged to high range of integrity respectively. Regarding self-development, 83.3 per cent, 66.7 per cent and 75.0 per cent of the rural, urban and total children belonged to high range of self-development respectively. In case of value orientation, majority $(78.3 \%$ and $61.7 \%$ ) of the sample from rural and urban area were having high range of value orientation followed by normal range. In case of commitment, 13.3 per cent and 86.7 per cent of rural children belonged to normal and high range of commitment respectively and 21.7 per cent and 78.3 per cent of urban children were under normal and high range of commitment respectively. With respect to altruistic behaviour, 83.3 per cent, 90.0 per cent and 86.7 per cent of rural, urban and total children belonged to high range of altruistic behaviour respectively. With regard to overall emotional intelligence, 76.7 per cent, 45.0 per cent and 60.8 per cent of the rural, urban and 
total children belonged to high range of emotional intelligence respectively and 23.3 per cent, 55.0 per cent and 39.2 per cent of rural, urban and total children belonged to normal range of emotional intelligence respectively. The result are in line with the study conducted by Punia and Sangwan (2011) revealed that majority of the children/ respondents had normal to high level of emotional intelligence and none were in low level of EI (Fig. 1).

Table.1 Demographic information of rural and urban children $\mathrm{N}=120$

\begin{tabular}{|c|c|c|c|c|c|c|c|}
\hline \multirow[t]{2}{*}{$\begin{array}{l}\text { Sl. } \\
\text { No }\end{array}$} & \multirow[t]{2}{*}{ Variables } & \multicolumn{2}{|c|}{$\begin{array}{l}\text { Rural } \\
(\mathrm{n}=60)\end{array}$} & \multicolumn{2}{|c|}{$\begin{array}{l}\text { Urban } \\
(\mathbf{n}=60)\end{array}$} & \multicolumn{2}{|c|}{$\begin{array}{c}\text { Total } \\
(\mathbf{N}=\mathbf{1 2 0})\end{array}$} \\
\hline & & $\mathrm{F}$ & $\%$ & $\mathrm{~F}$ & $\%$ & $\mathrm{~F}$ & $\%$ \\
\hline \multirow[t]{3}{*}{1} & \multicolumn{7}{|l|}{ Gender } \\
\hline & Male & 31 & 51.7 & 32 & 53.3 & 63 & 52.5 \\
\hline & Female & 29 & 48.3 & 28 & 46.7 & 57 & 47.5 \\
\hline \multirow[t]{4}{*}{2} & \multicolumn{7}{|l|}{ Age (years) } \\
\hline & $7-8$ & 14 & 23.3 & 19 & 31.7 & 33 & 37.5 \\
\hline & $9-10$ & 22 & 36.7 & 28 & 46.7 & 50 & 41.7 \\
\hline & $11-12$ & 24 & 40.0 & 13 & 21.7 & 37 & 30.8 \\
\hline \multirow[t]{3}{*}{3} & \multicolumn{7}{|l|}{ Birth order } \\
\hline & First born & 25 & 41.7 & 33 & 55.0 & 58 & 48.3 \\
\hline & Later born & 35 & 58.3 & 27 & 45.0 & 62 & 51.7 \\
\hline \multirow[t]{4}{*}{4} & \multicolumn{7}{|l|}{ No of siblings } \\
\hline & Nil & 3 & 5.0 & 10 & 16.7 & 13 & 10.8 \\
\hline & One & 30 & 50.0 & 26 & 43.3 & 56 & 46.7 \\
\hline & 2 and more & 27 & 45.0 & 24 & 40.0 & 51 & 42.5 \\
\hline \multirow[t]{3}{*}{5.} & \multicolumn{7}{|l|}{ Family type } \\
\hline & Nuclear & 49 & 81.7 & 50 & 75.0 & 99 & 82.5 \\
\hline & Joint & 11 & 18.3 & 10 & 25.0 & 21 & 17.5 \\
\hline \multirow[t]{4}{*}{6} & \multicolumn{7}{|l|}{ Family size } \\
\hline & Small & 33 & 55.0 & 37 & 61.7 & 70 & 58.3 \\
\hline & Medium & 18 & 30.0 & 16 & 26.7 & 34 & 28.3 \\
\hline & Large & 9 & 15.0 & 7 & 11.7 & 16 & 13.3 \\
\hline \multirow[t]{7}{*}{7.} & \multicolumn{7}{|c|}{ Socio-economic status } \\
\hline & Upper high & - & - & - & - & - & - \\
\hline & High & - & - & - & - & - & - \\
\hline & $\begin{array}{l}\text { Upper middle } \\
\text { SES }\end{array}$ & 13 & 21.7 & 17 & 28.3 & 30 & 25.0 \\
\hline & $\begin{array}{l}\text { Lowe middle } \\
\text { SES }\end{array}$ & 47 & 78.3 & 43 & 71.7 & 90 & 75.0 \\
\hline & Poor middle & - & - & - & - & - & - \\
\hline & Poor & - & - & - & - & - & - \\
\hline
\end{tabular}

Figures in parenthesis indicate percentages 
Table.2 Percentage distribution of emotional intelligence of children by locality

\begin{tabular}{|c|c|c|c|c|c|c|c|}
\hline \multirow[t]{2}{*}{ Sl.no } & \multirow{2}{*}{$\begin{array}{c}\text { Emotional } \\
\text { intelligence and its } \\
\text { areas }\end{array}$} & \multicolumn{2}{|c|}{ Rural } & \multicolumn{2}{|c|}{ Urban } & \multicolumn{2}{|c|}{ Total } \\
\hline & & $\begin{array}{l}\text { Normal } \\
\text { Range }\end{array}$ & $\begin{array}{l}\text { High } \\
\text { range }\end{array}$ & $\begin{array}{c}\text { Normal } \\
\text { Range }\end{array}$ & $\begin{array}{l}\text { High } \\
\text { range }\end{array}$ & $\begin{array}{l}\text { Normal } \\
\text { Range }\end{array}$ & High range \\
\hline 1 & Self awareness & $11(18.3)$ & $49(81.7)$ & $4(6.7)$ & $56(93.3)$ & $15(12.5)$ & $105(87.5)$ \\
\hline 2 & Empathy & $15(25.0)$ & $45(75.0)$ & $17(28.3)$ & $43(71.7)$ & $32(6.7)$ & $88(73.3)$ \\
\hline 3 & Self-motivation & $10(16.7)$ & $50(83.3)$ & $10(16.7)$ & $50(83.3)$ & $20(16.7)$ & $100(83.3)$ \\
\hline 4 & Emotional stability & $11(18.3)$ & $49(81.7)$ & $9(15.0)$ & $51(85.0)$ & $20(16.7)$ & $100(83.3)$ \\
\hline 5 & Managing relations & $29(48.3)$ & $31(51.7)$ & $13(21.7)$ & $47(78.3)$ & $42(35.0)$ & $78(65.0)$ \\
\hline 6 & Integrity & $7(11.7)$ & $53(88.3)$ & $5(8.3)$ & $55(91.7)$ & $12(10.0)$ & $108(90.0)$ \\
\hline 7 & Self-development & $10(16.7)$ & $50(83.3)$ & $20(33.3)$ & $40(66.7)$ & $30(25.0)$ & $90(75.0)$ \\
\hline 8 & Value orientation & $13(21.7)$ & $47(78.3)$ & $23(38.3)$ & $37(61.7)$ & $36(30.0)$ & $84(70.0)$ \\
\hline 9 & Commitment & $8(13.3)$ & $52(86.7)$ & $13(21.7)$ & $47(78.3)$ & $21(17.5)$ & $99(82.5)$ \\
\hline 10 & $\begin{array}{l}\text { Altruistic } \\
\text { Behaviour }\end{array}$ & $10(16.7)$ & $50(83.3)$ & $6(10.0)$ & $54(90.0)$ & $16(13.3)$ & 104(86.7) \\
\hline 11 & $\begin{array}{l}\text { Overall Emotional } \\
\text { Intelligence }\end{array}$ & $14(23.3)$ & $46(76.7)$ & $33(55.0)$ & $27(45.0)$ & $47(39.2)$ & $73(60.8)$ \\
\hline
\end{tabular}

Table.3 Percentage distribution and comparison of emotional intelligence of children by locality

\begin{tabular}{|c|l|l|l|l|l|l|l|l|}
\hline \multicolumn{2}{|c|}{} & \multicolumn{3}{|l|}{ Emotional intelligence } & & & & \\
\multicolumn{2}{|c|}{ Variables } & $\begin{array}{l}\text { Normal } \\
\text { range }\end{array}$ & $\begin{array}{l}\text { High } \\
\text { range }\end{array}$ & Total & & & & \\
\hline \multirow{2}{*}{ Locality } & Rural & $14(23.3)$ & $46(76.7)$ & $60(100.0)$ & X2 & R & M \pm SD & t value \\
\hline & Urban & $33(55.0)$ & $27(45.0)$ & $60(100.0)$ & $\mathbf{1 2 . 6 2 6 * * *}$ & $\mathbf{0 . 1 8 9 *}$ & $113.98 \pm 11.14$ & \\
\hline
\end{tabular}

Figures in parenthesis indicate percentages, *significant at 0.05 level of significance, **significance at 0.01 level of significance

Table.4 Comparison between areas of emotional intelligence and locality of children

\begin{tabular}{|c|l|c|c|c|}
\hline Sl.no & $\begin{array}{c}\text { Areas of emotional } \\
\text { intelligence vs locality }\end{array}$ & $\begin{array}{c}\text { Rural } \\
\mathbf{M} \pm \text { SD }\end{array}$ & $\begin{array}{c}\text { Urban } \\
\mathbf{M} \pm \text { SD }\end{array}$ & t value \\
\hline $\mathbf{1}$ & Self awareness & $13.43 \pm 2.59$ & $14.85 \pm 2.55$ & $3.010^{* *}$ \\
\hline $\mathbf{2}$ & Empathy & $16.55 \pm 3.03$ & $17.35 \pm 2.93$ & $1.466^{\mathrm{NS}}$ \\
\hline $\mathbf{3}$ & Self-motivation & $20.96 \pm 3.13$ & $20.45 \pm 2.55$ & $0.990 \mathrm{NS}$ \\
\hline $\mathbf{4}$ & Emotional stability & $13.95 \pm 3.00$ & $13.25 \pm 2.03$ & 1.493 \\
\hline $\mathbf{5}$ & Managing relations & $11.50 \pm 2.40$ & $14.35 \pm 2.32$ & $6.607 * * *$ \\
\hline $\mathbf{6}$ & Integrity & $9.96 \pm 2.32$ & $11.05 \pm 2.14$ & $2.656^{* *}$ \\
\hline $\mathbf{7}$ & Self-development & $6.93 \pm 1.53$ & $6.81 \pm 1.45$ & 0.427 \\
\hline $\mathbf{8}$ & Value orientation & $6.45 \pm 1.41$ & $6.96 \pm 1.87$ & 1.701 \\
\hline $\mathbf{9}$ & Commitment & $7.00 \pm 1.55$ & $6.68 \pm 1.62$ & 1.082 \\
\hline $\mathbf{1 0}$ & Altruistic Behaviour & $7.23 \pm 1.71$ & $7.13 \pm 1.43$ & 0.347 \\
\hline
\end{tabular}

*significant at 0.05 level of significance, ${ }^{* *}$ significance at 0.01 level of significance 
Table.5 Predictor variables (step wise regression) of emotional intelligence of children

\begin{tabular}{|l|l|c|c|c|c|c|}
\hline \multicolumn{7}{|c|}{ ANOVA } \\
\hline \multirow{2}{*}{ Model } & & Sum of Squares & df & Mean Square & F & Sig. \\
\hline 1 & Regression & 915.273 & 1 & 915.273 & 6.643 & $.011^{\text {a }}$ \\
\cline { 2 - 7 } & Residual & 16258.719 & 118 & 137.786 & & \\
\cline { 2 - 7 } & Total & 17173.992 & 119 & & & \\
\hline \multirow{2}{*}{2} & Regression & 1560.861 & 2 & 780.431 & 5.848 & $.004^{\text {b }}$ \\
\cline { 2 - 7 } & Residual & 15613.131 & 117 & 133.446 & & \\
\cline { 2 - 7 } & Total & 17173.992 & 119 & & & \\
\hline \multirow{2}{*}{ a. Predictors: (Constant), Family type } & & & \\
\hline b. Predictors: (Constant), Family type, Locality & & & \\
\hline
\end{tabular}

\begin{tabular}{|c|c|c|c|c|c|c|c|c|c|}
\hline \multicolumn{10}{|c|}{ Model Summary } \\
\hline \multirow[t]{2}{*}{ Model } & \multirow[t]{2}{*}{$\mathrm{R}$} & \multirow{2}{*}{$\begin{array}{c}\mathrm{R} \\
\text { Square }\end{array}$} & \multirow{2}{*}{$\begin{array}{l}\text { Adjusted R } \\
\text { Square }\end{array}$} & \multirow{2}{*}{$\begin{array}{l}\text { Std. Error } \\
\text { of the } \\
\text { Estimate }\end{array}$} & \multicolumn{5}{|c|}{ Change Statistics } \\
\hline & & & & & $\begin{array}{l}\text { R Square } \\
\text { Change }\end{array}$ & $\begin{array}{c}\mathrm{F} \\
\text { Change }\end{array}$ & df1 & df2 & $\begin{array}{c}\text { Sig. F } \\
\text { Change }\end{array}$ \\
\hline 1 & $.231^{\mathrm{a}}$ & .053 & .045 & 11.73822 & .053 & 6.643 & 1 & 118 & .011 \\
\hline 2 & $.301^{\mathrm{b}}$ & .091 & .075 & 11.55186 & .038 & 4.838 & 1 & 117 & .030 \\
\hline
\end{tabular}

Fig.1 Percentage distribution of Emotional intelligence of children by locality

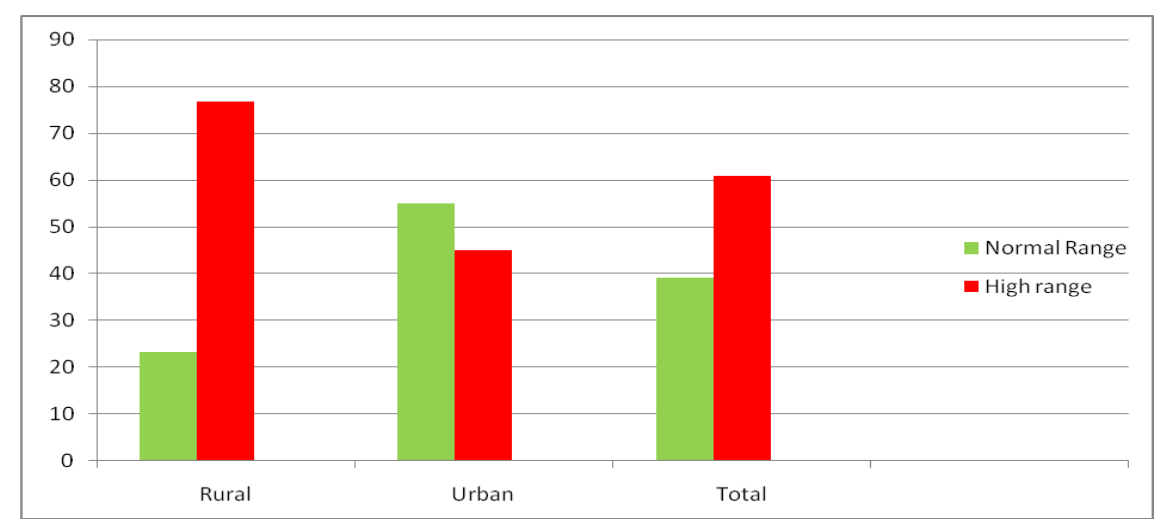

Figures in parenthesis indicate percentages

Table. 3 indicates percentage distribution and comparison of emotional intelligence of children by locality. Majority of the children from both rural and urban areas were found in high range of emotional intelligence $(76.7 \%$ and $45.0 \%$ respectively) and about 23.3 per cent and 55.0 per cent were found in normal range of emotional intelligence in rural and urban area. There was significant association, relation and difference between emotional intelligence and locality. As per the mean values, children from urban area found to have higher emotional intelligence than rural children. The results are on par with study conducted by, Henrera et al., (2017) and Punia and Sangwan (2011) found that the emotional intelligence of urban student was higher than that of rural students.

Table. 4 reveals the comparison between areas of emotional intelligence and locality of children. This table showed that, there was significant difference between rural an urban areas children with respect to self awareness, 
managing relations and integrity and as per mean values, children from urban areas were better than children from rural areas. There was no significant difference between locality with respect to empathy, self-motivation, emotional stability, self-development, value orientation, commitment and altruistic behaviour. The predictor variables of emotional intelligence of children are presented in table 5. Among all the independent variables, family type and locality were found to be significantly predicting the emotional intelligence of children in Belthangadi taluk. They together explained 9.0 per cent of variance in emotional intelligence of children. Shanwal et al., (2006) revealed that family size and type influenced the emotional intelligence of children.

In conclusion with respect to overall emotional intelligence, 76.7 per cent, 45.0 per cent and 60.8 per cent of the rural, urban and total children belonged to high range of emotional intelligence respectively. There was significant association, relation and difference between emotional intelligence and locality. As per the mean values, children from urban area found to have higher emotional intelligence than rural children. There was significant difference between rural an urban areas children with respect to self awareness, managing relations and integrity and as per mean values, children from urban areas were better than children from rural areas. Family type and locality were found to be significantly predicting the emotional intelligence of children in
Belthangadi taluk. They together explained 9.0 per cent of variance in emotional intelligence of children.

\section{References}

Aggarwal, O. P., Bhasin, S. K., Sharma, A. K. C., Aggarwal, K. and Rajoura, O. P., 2005, A new instrument (scale) for measuring the socio-economic status of a family: Preliminary study. Indian $J$. Comm. Med., 34(4):111-114.

Goleman, D., 1995, Emotional intelligence, New-York: Batman Books.

Herreraa, L., E. Buitrago, E. R. and Cepero, S., 2017, Emotional Intelligence in Colombian Primary School Children: Location and Gender. Universitas Psychologica, 16(3): 1-10

Mayer, J. D. and Salovey, P., 1993, The intelligence of emotional intelligence. Intelligence., 17: 433-442.

Mayer, J. D. and Salovey, P., 1997, What is emotional intelligence? In P. Salovey and D. Sluyster (Eds.) emotional development and emotional intelligence: implications for educators, New York, Basic Books, pp. 3-31.

Punia, S. and Santosh Sangwan, S., 2011, Emotional Intelligence and Social Adaptation of School Children. J Psychology, 2(2): 83-87

Shanwal,V. K., Kaur, G., Singh, S.B. and Kumar, S., 2006, Emotional Intelligence in School Children: A Socio Demographic Study. J. of Psy. Res., 1(1):1-13

\section{How to cite this article:}

Daneshwari Onkari, Sushma, Gowthami and Nishmitha. 2020. Emotional Intelligence of School Children. Int.J.Curr.Microbiol.App.Sci. 9(09): 3694-3700. doi: https://doi.org/10.20546/ijcmas.2020.909.456 